\title{
Ice thickness, growth and salinity in Van Mijenfjorden, Svalbard, Norway
}

Knut V. Høyland

The University Centre in Svalbard, P.O. Box 156, NO-9171 Longyearbyen, Norway/The Norwegian University of Science and Technology, No-7491 Trondheim, Norway

\section{Keywords}

Fjord; ice thermodynamics; ice thickness; measurements; oceanic flux; Svalbard.

\section{Correspondence}

Knut V. Høyland, The University Centre in

Svalbard, P.O. Box 156, NO-9171

Longyearbyen, Norway/The Norwegian

University of Science and Technology,

NO-7491 Trondheim, Norway. E-mail:

knut.hoyland@ntnu.no

doi:10.1111/j.1751-8369.2009.00133.x

\begin{abstract}
This paper describes measurements of ice conditions in the fjord Van Mijenfjorden, Spitsbergen, in the Svalbard Archipelago, between 1998 and 2006. Ice thickness, ice temperatures and ice properties were measured, and simple simulations of oceanic flux were performed. The maximum annual peak ice thickness was measured in 2004: $1.3 \mathrm{~m}$ in the inner basin and $1.2 \mathrm{~m}$ in the outer basin. The minimum annual peak thickness was $0.72 \mathrm{~m}$ in the inner basin and no fast ice in the outer basin, in 2006. The estimated oceanic flux was about $2-5 \mathrm{~W} \mathrm{~m}^{-2}$ in the outer basin, and was close to zero in the inner basin. Flooding and brine drainage may have caused an overestimation of the oceanic flux. The measurements demonstrate different ice growth mechanisms, and the simplest model (Stefan's Law with air temperatures and a correction factor) fails to predict the ice growth. Finally, there is reason to believe that the ice conditions were heavier in the 1980s.
\end{abstract}

Sea ice insulates the warm ocean from the cold atmosphere during the winter, and the freezing and melting of sea ice produce salt- and freshwater, respectively. In this way, sea ice plays a key role in the thermohaline circulation in icy waters, and because of this it also has an impact on the climate on a global scale. For engineers, sea ice is a critical factor in the design of structures such as ships, harbours, platforms, bridges and pipelines in Arctic waters.

The thickness, temperature and salinity of ice cover are vital for many thermomechanical properties that affect, for example, the ice action on structures and ships, as well as the ocean-ice-atmosphere heat exchange and the thermohaline circulation.

The fjord Van Mijenfjorden, located on the western side of the island of Spitsbergen (Fig. 1), in the Svalbard Archipelago in the north-western Barents Sea, offers favourable conditions for studying sea ice. The mouth of the fjord is almost closed off by the small island Akseløya, ensuring a fairly stable ice cover on the fjord from December/January until June/early July. At the head of the fjord lies Svea Nord, the main mine of Store Norske Spitsbergen Kullkompani (the Norwegian Coal Mining Company). The coal is shipped out from the harbour at
Kapp Amsterdam (Fig. 1). The shipping season is limited by the sea ice, and historically this has imposed a restriction on coal production.

Since 1997, the departments of Arctic Geophysics and Arctic Technology at the University Centre in Svalbard (UNIS) have undertaken a range of ice investigations, and many Master's and PhD theses are fully or partly based on fieldwork in Van Mijenfjorden. In addition to investigations of ice thickness and growth, as described in this paper, UNIS has worked with the mechanical behaviour of sea ice, and on ice ridge consolidation. During the years 2002-2007, measurements of internal ice stresses in the ice cover, and sampling and testing of small-scale mechanical properties, were carried out by UNIS's Department of Arctic Technology. Results from these campaigns have been presented in Moslet (2001), Moslet \& Høyland (2003), Teigen et al. (2005), Shafrova 8 Moslet (2006a, b), Moslet (2007), Barrault \& Høyland (2007), Caline $\delta$ Barrault (2008) and Gabrielsen et al. (2008). The work on ice ridge consolidation was carried out from 1997 to 1999; an overview is given in Høyland (2002). The present paper deals with ice thickness and ice growth in Van Mijenfjorden, and attempts to summarize our present knowledge on ice growth, ice thickness and salinity. 


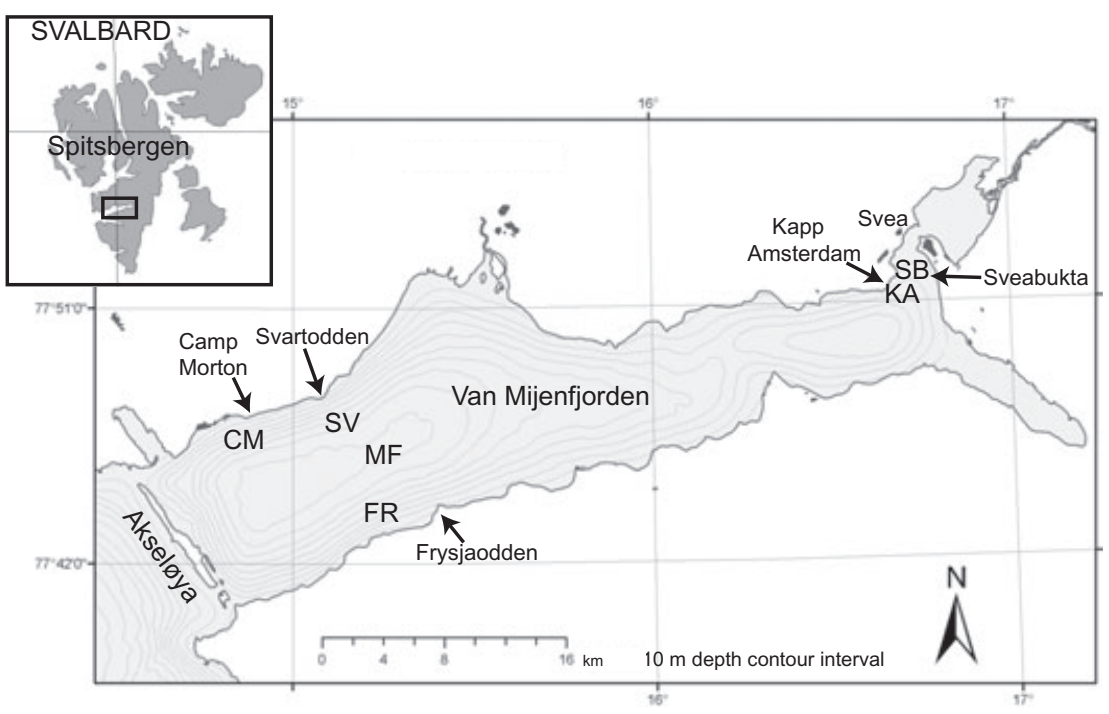

Fig. 1 Map of Van Mijenfjorden, showing the locations and abbreviated names of the stations (based on a map kindly furnished by the Department of Marine Ecology, Institute of Oceanology, Sopot, Poland, available at http:// www.iopan.gda.pl). The following stations were located in the outer basin, which is about $10 \mathrm{~km}$ wide and about $100 \mathrm{~m}$ deep (Kangas

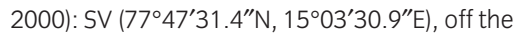
point of Svartodden; CM, off Camp Morton; FR $\left(77^{\circ} 42^{\prime} 57.1^{\prime \prime} \mathrm{N}, 15^{\circ} 10^{\prime} 16.0^{\prime \prime} \mathrm{E}\right)$, west of the point of Frysjaodden; MF, the 1998 station in the middle of the fjord. The following stations were located in the inner basin, which is typically $5 \mathrm{~km}$ wide, and has an average depth of about $30 \mathrm{~m}$ (Kangas 2000): KA $\left(77^{\circ} 2^{\prime} \mathrm{N}\right.$, $\left.16^{\circ} 40^{\prime} \mathrm{E}\right)$, off Kapp Amsterdam; SB (77.52'25.2"N, $\left.16^{\circ} 43^{\prime} 93.8^{\prime \prime} \mathrm{E}\right)$ in the bay Sveabukta.

\section{Methods}

\section{Ice growth (and melting) mechanisms}

New ice can grow (and melt) at the top, in the interior or at the bottom of the ice cover. Ice growth at the bottom of the ice cover is often the dominating mechanism, and can be described by analytical or numerical solutions. Maykut \& Understerner (1971) came up with the first numerical solution based on the heat transfer equation, and they used this solution to estimate the ice thickness in the Arctic Basin. However, the simplest model is Stefan's Law (Stefan 1891), which can be expressed as follows:

$$
h_{i}^{2}=h_{i, 0}^{2}+\frac{2 k}{\rho \cdot l} \sum_{n}\left(T_{\mathrm{f}}-T_{\mathrm{is}}\right),
$$

where $h_{\mathrm{i}}$ and $h_{\mathrm{i}, 0}$ are the current and the initial ice thicknesses, $k$ is the thermal conductivity, $\rho$ is the density, $l$ is the latent heat, $T_{\mathrm{f}}$ is the freezing point, $T_{\text {is }}$ is the daily average ice surface temperature and $n$ is the number of days. The ice surface temperature is often not accessible, and therefore one often uses the air temperature $\left(T_{a}\right)$, and defines the freezing degree days (FDDs) in the time span $\left(t_{0}, t\right)$ :

$$
F D D=\int_{t_{0}}^{t}\left(\max \left(0, T_{\mathrm{f}}-T_{\mathrm{a}}\right)\right) \mathrm{d} t
$$

If one further introduces an empirical coefficient $\omega$ to account for simplifications in the model, Stefan's Law becomes:

$$
h_{i}^{2}=h_{i, 0}^{2}+\omega \frac{2 k}{\rho \cdot l} F D D .
$$

See, for example, Leppäranta (1993) for an overview of sea ice growth models.
Ice may also grow on top of the primary layer in the original ice cover, either because of flooding of sea water or because of rain/snow melting. The terminology of this type of ice is not clear. Michel \& Ramseier (1971) define it as "superimposed ice", regardless of the mode of formation, whereas Nicolaus et al. (2003) and Eicken et al. (1995) distinguish between "snow ice" and "superimposed ice". Snow ice is created when the ice is flooded by sea water, for example as a result of snow precipitation, and the soaked snow freezes. This ice has a high salinity, and can easily be detected from salinity profiles. "Superimposed ice", in the terminology of Nicolaus et al. (2003) and Eicken et al. (1995), forms from the presence of freshwater. When it rains, or the snow for some reason melts, the meltwater will freeze when it meets belowzero temperatures. Such ice is relatively fresh and often highly porous. This latter phenomenon may also create icy layers in the snow pack. In this paper, I will avoid the term "superimposed ice" and use "top ice" to refer to all ice formed on top of the original ice cover.

Finally, new ice can be created/melted inside the ice cover. This happens partly because the temperature changes and some brine freezes/melts to keep the brine temperature at the freezing point, and partly when water (brine or fresh) drizzles down through the ice and freezes/ melts ice to keep the liquid at the freezing point. The major importance of the internal freezing/melting is the desalination and the deterioration of the ice, and, furthermore, the effect on the thermohaline circulation. But, the pure thermal effects of this exothermal/endothermal process may also be interesting. When brine drains towards a positive temperature gradient it melts ice and consumes heat, whereas when it drains in a negative temperature gradient new ice is created and the ice is heated. 


\section{Heat balance and numerical scheme}

The heat flux balance in the lower layers of a growing ice sheet is shown in Fig. 2, and can be expressed by the following heat flux balance:

$$
q_{\text {ocean }}+q_{\mathrm{i}}+q_{\text {lat }}=0
$$

where $q_{\text {ocean }}$ is the flux coming from the water-the oceanic heat flux, $q_{\mathrm{i}}$ is the flux up through the ice coveroften given as the heat conductive flux, although it also incorporates convective fluxes, and $q_{\text {lat }}$ is the flux released/consumed as ice grows or melts (at the bottom or internally). The flux through the ice can be estimated using Fourier's Law $\left(q_{\mathrm{i}}=-k T, z\right)$ and the latent heat (for ice growth at the bottom) $q_{\text {lat }}=\rho l \mathrm{~d} h / \mathrm{d} t$, where $k$ is the thermal conductivity, $T_{z}$ is the temperature gradient, $\rho$ is the density, $l$ is the latent heat and $\mathrm{d} h / \mathrm{d} t$ is the ice growth velocity.

By using measured temperature profiles (between four and eight nodes were used) and measured ice thicknesses $(\Delta h)$, the average oceanic flux over a time period $t=\Sigma \Delta t_{j}$ can be estimated as follows (using the coordinate system on Fig. 2):

$$
\begin{gathered}
q_{\text {ocean }}=k \cdot T_{, i}-\rho \cdot l \cdot \dot{h} \Rightarrow \\
q_{\text {ocean }}=\left[k \sum\left(\frac{\Delta T}{\Delta z}\right)_{j} \Delta t_{j}-\rho l \Delta h\right] / \sum \Delta t_{j} .
\end{gathered}
$$

If the oceanic flux is neglected, an upper limit for the ice growth can be estimated:

$$
\Delta h_{\max }=\frac{k}{\rho l} \frac{\Delta T}{\Delta z} \Delta t .
$$

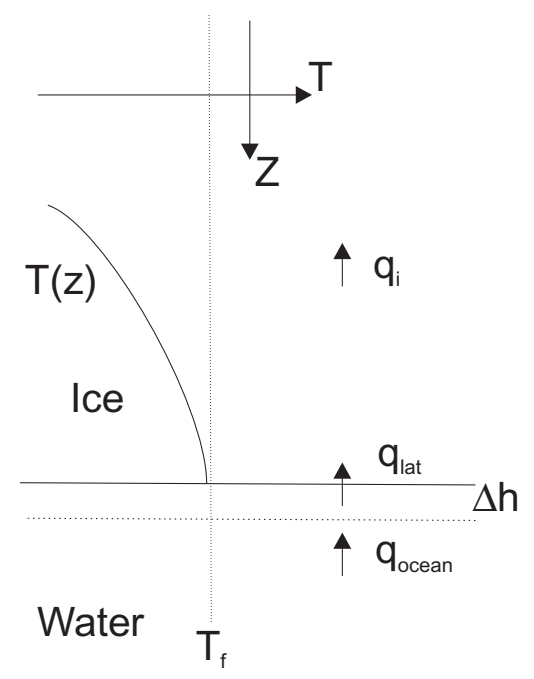

Fig. 2 The thermal balance in the lower parts of ice cover.

\section{Site and experimental methods}

Measurements of ice thickness and growth in Van Mijenfjorden were made during the years 1998-2004 and in 2006. About $70 \mathrm{~km}$ long, the fjord is situated on the west coast of Spitsbergen, about $60 \mathrm{~km}$ from Longyearbyen (Fig. 1). The mouth of the fjord is almost blocked by the island Akseløya. The fjord is often divided into an outer and an inner basin (Kangas 2000), and the tidal current dominates the currents (Bergh 2004). The field station locations (and abbreviations) are shown in Fig. 1.

We measured ice and snow thicknesses (manually), ice and snow temperatures (automatically), ice salinity and ice density. Salinity was measured from ice cores. We sampled cores with a diameter of $70 \mathrm{~mm}$ that were then cut into pieces ranging from $50 \mathrm{~mm}$ (2003, 2004 and 2006) up to $100 \mathrm{~mm}$ in length, and which were subsequently melted and measured. The density was measured by coring cylindrical samples, cutting them into $175-\mathrm{mm}$ long samples, assuming perfect cylindrical shape, and measuring their weight. The weather stations in Svea (Norwegian Meteorological Institute, the Norwegian Geotechnical Institute and the one at the Svea airfield) provided the meteorological data. In 1998, 2002, 2003 and 2004, oceanic and meteorological measurements were also performed in the outer basin, as part of the UNIS course AGF-211 (Frank Nilsen, UNIS, pers. comm.). Table 1 gives an overview of when the different measurements were made in the inner and the outer basins.

Thermistor strings (EBA Engineering, Edmonton, Canada), with up to 16 thermistors and a resolution of $0.1 \mathrm{~m}$, were installed so that the temperatures in the snow, through the ice cover, and in the water were measured automatically. The temperatures were measured either hourly or every sixth hour. The strings were taped to bamboo sticks and inserted in 0.05-m diameter drilled holes in the ice. The strings froze in position, and were normally recovered by the end of the season. The strings and bamboo sticks also made it easy to detect any top-ice growth.

The vertical temperature profiles throughout the ice cover were used to estimate the ice thickness by assuming that the ice temperatures were below the freezing point of the underlying water. With this method, failure to capture the total ice growth is a possibility, partly because the growth of top ice is not detected by a thermistor string, partly because the lowermost part of the ice cover is at the freezing point, and partly because it is more difficult to detect the ice-water interface when the ice is melting.

All the measurements were performed by UNIS staff or UNIS students. Whenever no source is cited, the work was carried out by the author and students in the UNIS course AT-208. 
Table 1 Overview of measurements taken in the inner and outer basins.

\begin{tabular}{|c|c|c|c|c|c|}
\hline \multirow[b]{3}{*}{ Type of measurement } & \multicolumn{5}{|l|}{ Dates } \\
\hline & \multicolumn{5}{|c|}{ Outer basin, stations MF, CM, SV and FR } \\
\hline & 1998 & 1999 & 2002 & 2003 & 2004 \\
\hline Thermistors in ice, snow and water (resolution $0.1 \mathrm{~m}$ ) & $03.03-12.05$ & $09.03-05.05$ & $27.02-25.04$ & $14.02-24.04$ & $29.01-05.06$ \\
\hline Thermistors in snow (resolution 0.025 m) & - & - & $27.02-25.04$ & $14.02-24.04$ & - \\
\hline Salinity & $\begin{array}{l}28.04 \\
12.05\end{array}$ & $\begin{array}{l}10.03 \\
05.05 \\
13.05\end{array}$ & $\begin{array}{l}27.02 \\
13.03\end{array}$ & $\begin{array}{l}14.02 \\
26.02 \\
12.03\end{array}$ & $\begin{array}{l}29.01 \\
23.03 \\
24.04 \\
01.05 \\
05.06 \\
06.06 \\
07.06\end{array}$ \\
\hline Ice thickness & $\begin{array}{l}03.03 \\
19.03 \\
25.03 \\
16.04 \\
28.04 \\
12.05\end{array}$ & $\begin{array}{l}10.03 \\
22.04 \\
13.05\end{array}$ & $\begin{array}{l}28.02 \\
03.03 \\
21.03 \\
03.04 \\
14.04 \\
28.04\end{array}$ & $\begin{array}{l}14.02 \\
26.02 \\
12.03 \\
23.04\end{array}$ & $\begin{array}{l}29.01 \\
23.03 \\
24.04 \\
01.05 \\
05.06 \\
06.06 \\
07.06\end{array}$ \\
\hline Snow depth & $\begin{array}{l}03.03 \\
21.05\end{array}$ & $\begin{array}{l}10.03 \\
22.04 \\
13.05\end{array}$ & $\begin{array}{l}28.02 \\
03.03 \\
21.03 \\
03.04 \\
14.04 \\
28.04\end{array}$ & $\begin{array}{l}14.02 \\
26.02 \\
12.03 \\
23.04\end{array}$ & $\begin{array}{l}29.01 \\
23.03 \\
24.04 \\
01.05 \\
05.06 \\
06.06 \\
07.06\end{array}$ \\
\hline \multirow[t]{3}{*}{ Freeboard } & $\begin{array}{l}03.03 \\
19.03 \\
25.03 \\
16.04 \\
28.04 \\
12.05\end{array}$ & $\begin{array}{l}10.03 \\
22.04 \\
13.05\end{array}$ & $\begin{array}{l}28.02 \\
03.03 \\
21.03 \\
03.04 \\
14.04 \\
28.04\end{array}$ & $\begin{array}{l}14.02 \\
26.02 \\
12.03 \\
23.04\end{array}$ & $\begin{array}{l}29.01 \\
23.03 \\
24.04 \\
01.05 \\
05.06 \\
06.06 \\
07.06\end{array}$ \\
\hline & \multicolumn{5}{|c|}{ Inner basin, stations KA and SB } \\
\hline & \multicolumn{2}{|l|}{2002} & 2003 & 2004 & 2006 \\
\hline Thermistors in ice, snow and water (resolution $0.1 \mathrm{~m}$ ) & \multicolumn{2}{|l|}{$26.02-27.04$} & $25.02-23.04$ & $28.01-21.04$ & $21.02-20.04$ \\
\hline Thermistors in snow (resolution 0.025 m) & \multicolumn{2}{|l|}{$26.02-27.04$} & $25.02-23.04$ & - & - \\
\hline Salinity & $\begin{array}{l}26.02 \\
12.03 \\
13.03 \\
03.04\end{array}$ & \multicolumn{2}{|c|}{$\begin{array}{l}20.02 \\
25.02 \\
11.03 \\
25.03 \\
27.03 \\
28.03 \\
24.04\end{array}$} & $\begin{array}{l}28.01 \\
17.02 \\
24.03 \\
20.04\end{array}$ & $\begin{array}{l}21.02 \\
22.02 \\
28.02 \\
16.03 \\
30.03 \\
11.04 \\
19.04 \\
20.04\end{array}$ \\
\hline Ice thickness & $\begin{array}{l}20.02 \\
26.02 \\
12.03 \\
03.04 \\
18.04 \\
14.05\end{array}$ & \multicolumn{2}{|c|}{$\begin{array}{l}20.02 \\
25.02 \\
11.03 \\
23.04\end{array}$} & $\begin{array}{l}28.01 \\
17.02 \\
24.03 \\
20.04\end{array}$ & $\begin{array}{l}09.01 \\
16.02 \\
21.02 \\
29.02 \\
16.03 \\
30.03 \\
11.04 \\
20.04\end{array}$ \\
\hline Snow depth & $\begin{array}{l}20.02, \\
26.02, \\
12.03, \\
03.04 \\
10.04 \\
18.04 \\
14.05\end{array}$ & \multicolumn{2}{|c|}{$\begin{array}{l}20.02 \\
25.02 \\
11.03 \\
23.04\end{array}$} & $\begin{array}{l}28.01 \\
17.02 \\
24.03 \\
20.04\end{array}$ & $\begin{array}{l}16.02 \\
21.02 \\
29.02 \\
16.03 \\
30.03 \\
11.04 \\
20.04\end{array}$ \\
\hline Freeboard & $\begin{array}{l}20.02 \\
26.02 \\
12.03 \\
03.04 \\
18.04 \\
14.05\end{array}$ & $\begin{array}{l}20 . \\
25 . \\
11 . \\
23 .\end{array}$ & & $\begin{array}{l}28.01 \\
17.02 \\
24.03 \\
20.04\end{array}$ & $\begin{array}{l}16.02, \\
21.02 \\
29.02 \\
16.03 \\
30.03 \\
11.04 \\
20.04\end{array}$ \\
\hline
\end{tabular}




\section{Results}

\section{Ice formation, ridging and ice break-up}

In the winter seasons of $1997 / 98$ and 2003/04, ice formed on the surface in the bay Sveabukta in early December. During both winters, there was much ice in the fjords of Svalbard. In 2005/06, the ice froze up in the inner basin in mid-January, whereas the outer basin never froze up.

The ice ridge density varied considerably: in 1997, 2003 and 2004 there were few ridges; in 1998, 1999 and 2002 there were more ridges. The blocks constituting the ice ridges were 0.10-0.15 m thick (measured in 1998, 1999, 2002, 2003 and 2006), and it seems that all the ridging activity occurred at the same time. We did not observe any deformation in the floating ice cover in the measurement periods, except for some thermal cracking. In 1999 and 2003, level ice thickness differences of about $0.1 \mathrm{~m}$ were observed over small horizontal distances $(1 \mathrm{~m})$, and we believe that these are remains of early rafting.

\section{Ice thickness}

Figures 3-5 give the measurements of ice thickness, snow depth and freeboard. Numerical values are given in Table 2. In general, the ice was thicker in the inner basin than in the outer basin. The maximum measured ice
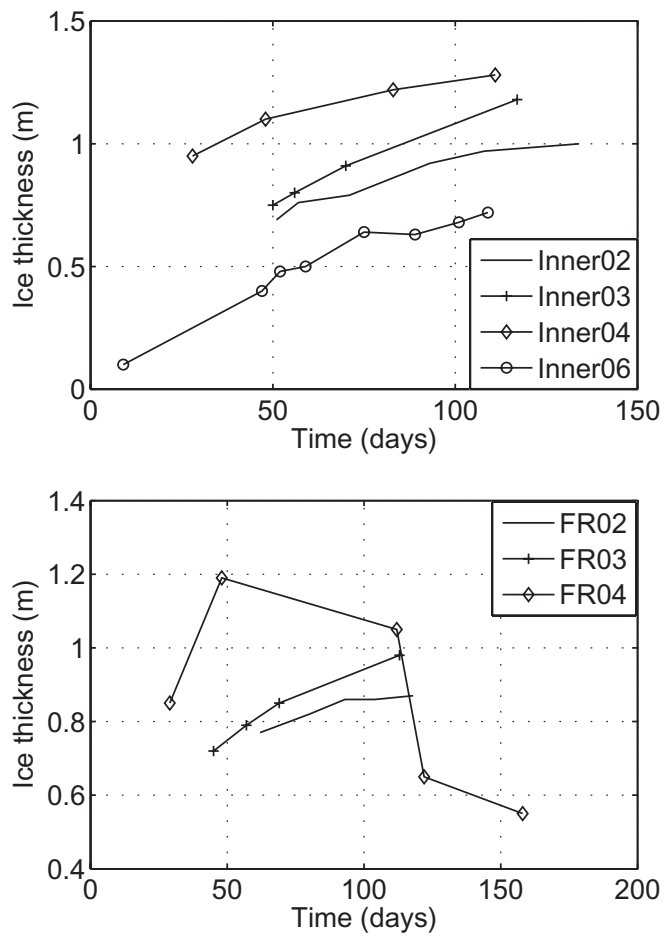

thickness in the inner basin was $1.28 \mathrm{~m}$ in Sveabukta (SB) in 2004. In the outer basin, the thickest ice was $1.19 \mathrm{~m}$ at FR in 2004, and $1.16 \mathrm{~m}$ at MF in 1998. Both winters were cold, but in 1998 the ice grew until midMay, whereas it stopped in late March (FR) and late April (SB) in 2004.

The maximum ice thickness was also greater on the southern side of the outer basin compared with the northern side. At SV, more snow accumulated in 2003 than in other years, but little ice was formed directly on top of the primary layer. However, we did observe icy layers in the snow pack.

The ice growth in 2004 took place early in the season (before mid-March), and most of the snow accumulated after this. The snow insulated the ice cover from the atmosphere during the warm period in March and April, so that the maximum ice thickness on the northern side $\mathrm{y}(\mathrm{SV})$ was about the same as on the southern side (FR): 1.15 versus $1.19 \mathrm{~m}$. The ice started to melt earlier at FR, and by 22 April it was thinner than at SV (1.05 vs. $1.15 \mathrm{~m}$ ). In early June, the ice on the southern side was $0.45-0.7 \mathrm{~m}$, whereas it was still about $1.15 \mathrm{~m}$ on the northern side.

As expected, the ice thicknesses derived from the thermistor strings $\left(h_{\mathrm{i}}^{\mathrm{T}}\right)$ were generally less than those measured manually $\left(h_{\mathrm{i}}^{\mathrm{M}}\right)$. The correspondence between the manually measured thickness and the ones derived
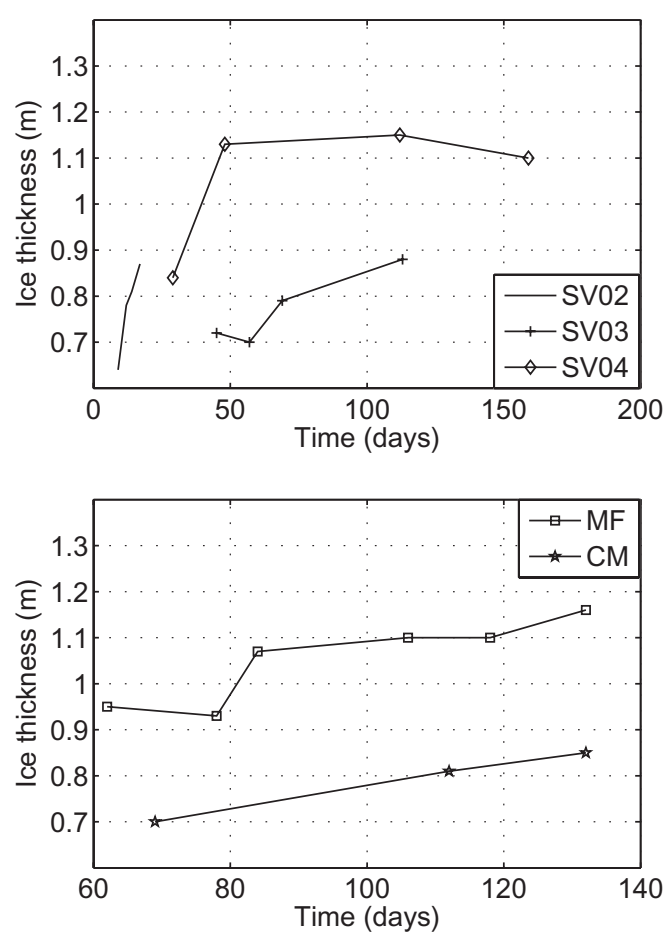

Fig. 3 Ice thickness measurements. 

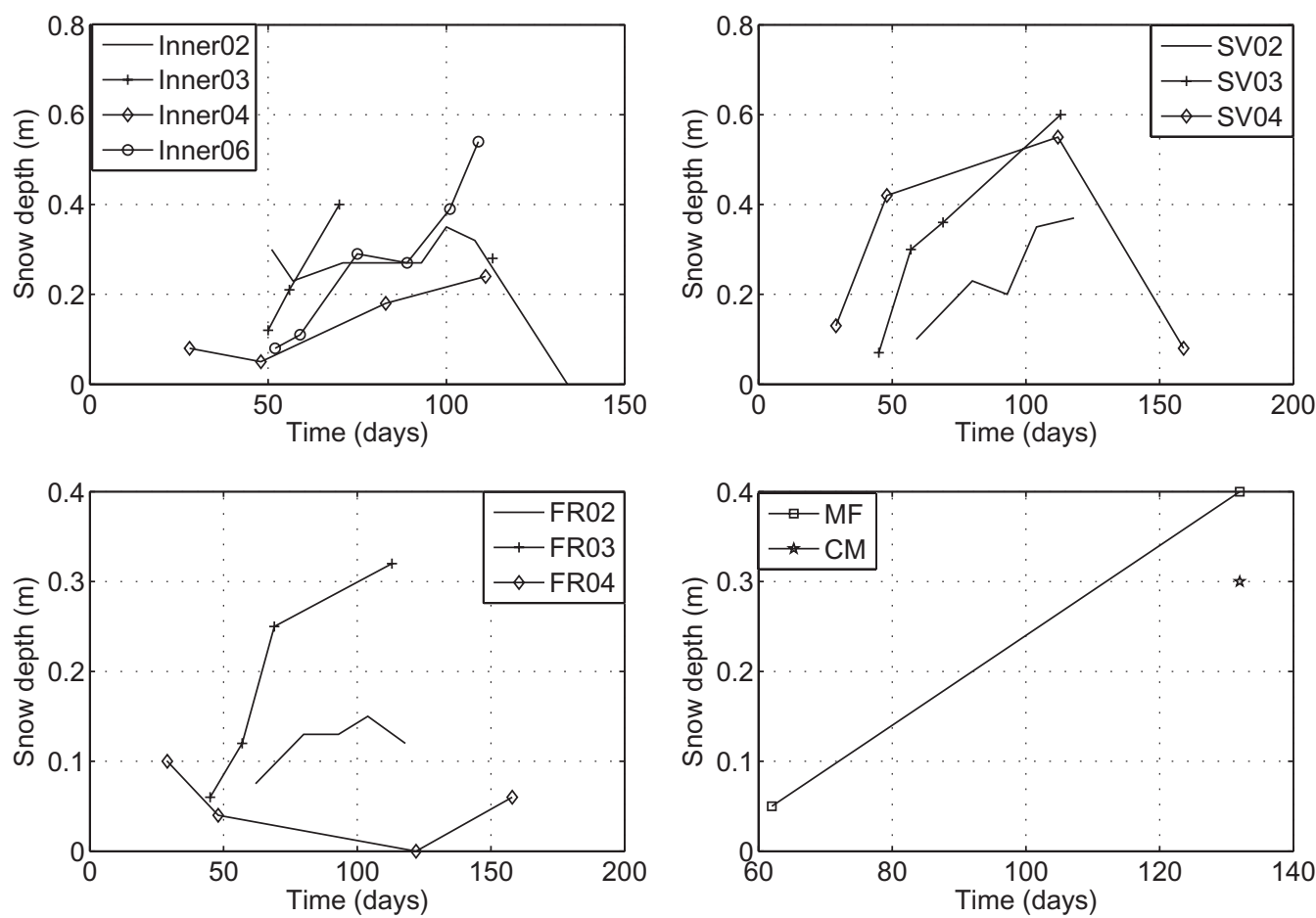

Fig. 4 Snow depth measurements.
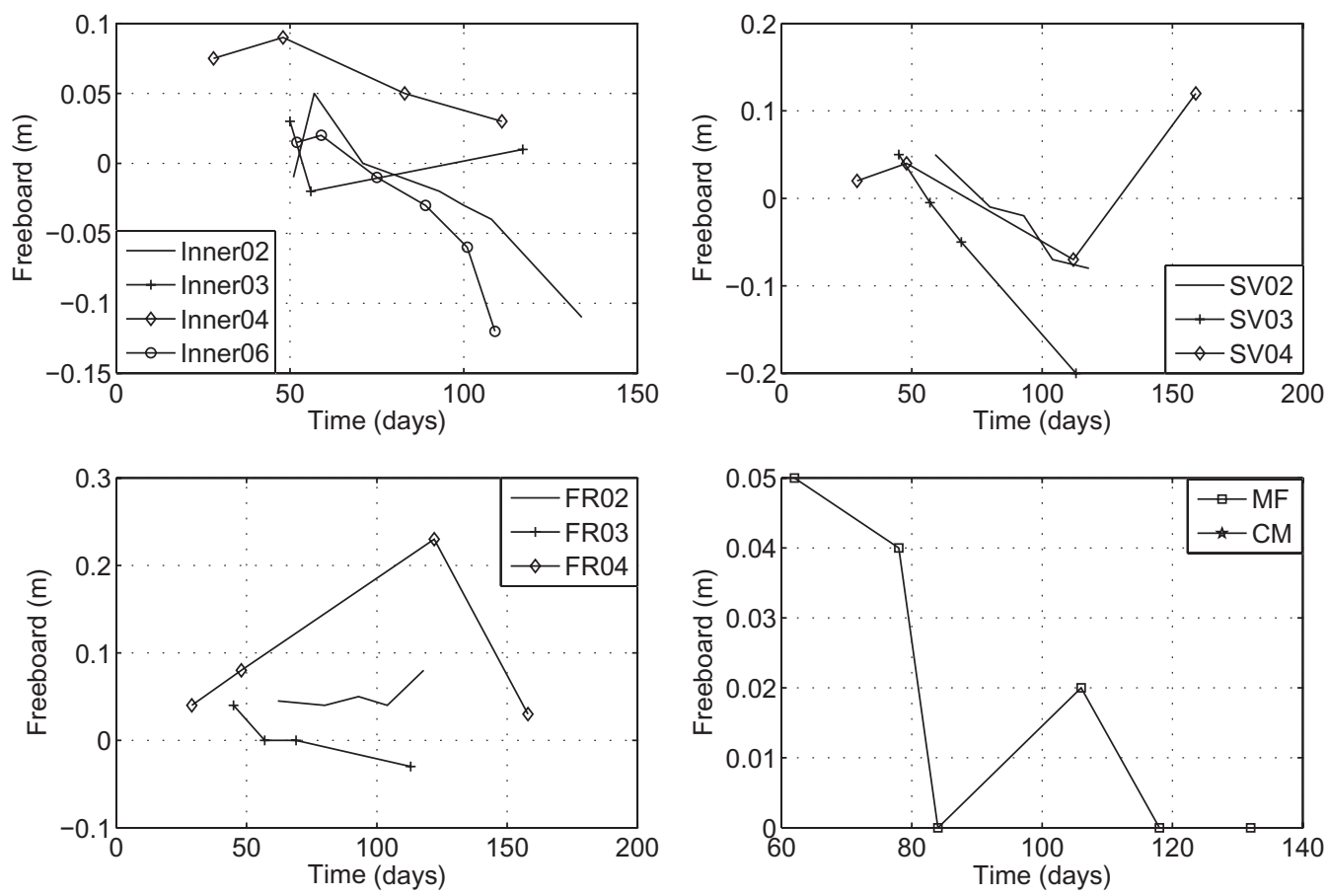

Fig. 5 Freeboard measurements. 
Table 2 Measurements of maximum ice and snow thickness $\left(h_{\mathrm{i}}\right.$ and $\left.h_{\mathrm{s}}\right)$ and freeboard (FB).

\begin{tabular}{|c|c|c|c|c|c|c|c|c|c|c|c|c|c|c|c|c|c|}
\hline \multirow{2}{*}{\multicolumn{2}{|c|}{ Station }} & \multicolumn{16}{|l|}{ Year } \\
\hline & & \multicolumn{2}{|l|}{2006} & \multicolumn{2}{|l|}{2004} & \multicolumn{2}{|l|}{2003} & \multicolumn{2}{|l|}{2002} & \multicolumn{2}{|l|}{2001} & \multicolumn{2}{|l|}{2000} & \multicolumn{2}{|l|}{1999} & \multicolumn{2}{|l|}{1998} \\
\hline \multirow[t]{4}{*}{ SB } & Date & 15.01 & 19.04 & 28.01 & 20.04 & 29.03 & 25.04 & & & & & & & & & & \\
\hline & $h_{i}$ & $0.1-0.15$ & 0.72 & 0.95 & 1.28 & 1.10 & 1.24 & & & & & & & & & & \\
\hline & $h_{s}$ & 0.02 & 0.54 & 0.08 & 0.24 & 0.05 & 0.18 & & & & & & & & & & \\
\hline & $\mathrm{FB}(\mathrm{m})$ & - & -0.12 & 0.08 & 0.09 & 0.07 & 0.08 & & & & & & & & & & \\
\hline \multirow[t]{4}{*}{ KA } & Date & & & & & & & 21.02 & 14.05 & 07.03 & 05.05 & 01.03 & 04.05 & & & & \\
\hline & $h_{i}$ & & & & & & & 0.69 & 1.0 & 0.65 & 0.99 & 0.64 & 0.84 & & & & \\
\hline & $h_{s}$ & & & & & & & 0.30 & 0 & 0.05 & & 0.12 & 0 & & & & \\
\hline & $\mathrm{FB}(\mathrm{m})$ & & & & & & & -0.01 & 0.11 & 0.05 & & 0.05 & 0.27 & & & & \\
\hline \multirow[t]{4}{*}{ FR } & Date & & & 29.01 & 23.03 & 14.02 & 23.04 & 03.03 & 25.04 & & & & & & & & \\
\hline & $h_{i}$ & No fast ice & & 0.85 & 1.19 & 0.72 & 1.0 & 0.77 & 0.87 & & & & & & & & \\
\hline & $h_{s}$ & & & 0.1 & 0.04 & 0.06 & 0.32 & 0.08 & 0.2 & & & & & & & & \\
\hline & $\mathrm{FB}(\mathrm{m})$ & & & 0.04 & 0.08 & 0.04 & -0.03 & 0.05 & 0.08 & & & & & & & & \\
\hline \multirow[t]{4}{*}{ SV } & Date & & & 29.01 & 23.03 & 14.02 & 23.04 & 27.02 & 25.04 & & & & & & & & \\
\hline & $h_{i}$ & No fast ice & & 0.84 & 1.15 & 0.71 & 0.88 & 0.66 & 0.87 & & & & & & & & \\
\hline & $h_{s}$ & & & 0.13 & 0.55 & 0.07 & 0.60 & 0.1 & 0.37 & & & & & & & & \\
\hline & $\mathrm{FB}(\mathrm{m})$ & - & & 0.02 & -0.07 & 0.05 & -0.2 & 0.05 & -0.08 & & & & & & & & \\
\hline \multirow[t]{4}{*}{$\mathrm{CM}$} & Date & & & & & & & & & & & & & 10.03 & 06.05 & & \\
\hline & $h_{i}$ & & & & & & & & & & & & & 0.70 & 0.85 & & \\
\hline & $h_{5}$ & & & & & & & & & & & & & & 0.3 & & \\
\hline & $\mathrm{FB}(\mathrm{m})$ & & & & & & & & & & & & & 0.05 & 0 & & \\
\hline \multirow[t]{4}{*}{ MF } & Date & & & & & & & & & & & & & & & 03.03 & 12.05 \\
\hline & $h_{i}$ & & & & & & & & & & & & & & & 0.95 & 1.16 \\
\hline & $h_{s}$ & & & & & & & & & & & & & & & & 0.4 \\
\hline & $\mathrm{FB}(\mathrm{m})$ & & & & & & & & & & & & & & & 0.05 & 0 \\
\hline
\end{tabular}

from temperature measurements $\left(h_{\mathrm{i}}^{\mathrm{M}}-h_{\mathrm{i}}^{\mathrm{T}}\right)$ was $0.1-0.2 \mathrm{~m}$ for all years at FR, $0-0.2 \mathrm{~m}$ at SV, $0.05-0.15 \mathrm{~m}$ at $\mathrm{CM}$ (1999), 0.1-0.15 $\mathrm{m}$ at SB (2006) and $0-0.1 \mathrm{~m}$ at KA (2002) and SB (2004). There was little top ice formation on the SB site in 2004, whereas top ice growth in the order of $5-10 \mathrm{~cm}$ was detected at FR and CM.

\section{Salinity and ice texture}

Figure 6 shows the bulk (or average) salinity measurements, and one can easily see how the average salinity decreased throughout the season. The average level was 6-8 ppt in early/mid-season, 4-6 ppt by the end of the growth season and 2-4 ppt during the melting period. Naturally, there was a further decrease in salinity, but we did not carry out measurements after early June.

The top ice formation can be seen from the salinity profiles in Figs. 7 and 8, either as ice with low salinity, created when the snow was soaked by rain or meltwater from the top snow layer (Fig. 7), or as ice with high salinity, created when the snow cover submerged the ice and the snow was soaked with seawater (Fig. 8). Figure 7 also shows how the peak salinity decreased and moved downwards in the ice cover between late March and late April.
The ice texture was examined in thin sections. In general, the ice was ordinary columnar ice, with a vertical crystal size of more than $0.1 \mathrm{~m}$, and a diameter of up to $0.03 \mathrm{~m}$.

\section{Numerical results}

Figure 9 shows selected temperature-depth plots for the FR station in 2003 and 2004. The cold winter and warm spring in 2004 are easily detected in the diagram.

Several calculations were performed on the basis of temperature records and equations 1, 3, 5 and 6. Table 3 gives the material parameters, and Fig. 10 and Table 4 show the results.

Equation 3 was first used to (1) estimate the ice growth (assuming $\omega=0$ ) and (2) determine the coefficient $\omega$ using the measured ice growth. Furthermore, the icesnow interface temperature was used to calculate the ice growth, as given in Eqn. 1. Finally, the measured temperature profiles were used to estimate the ice growth, as given in Eqn. 6

The oceanic flux was neglected in the abovementioned calculations. However, it was estimated on the basis of the measured ice thicknesses (Eqn. 5). The results are also given in Table 4. The oceanic flux was neither sensitive to the number of nodes used to calculate the 

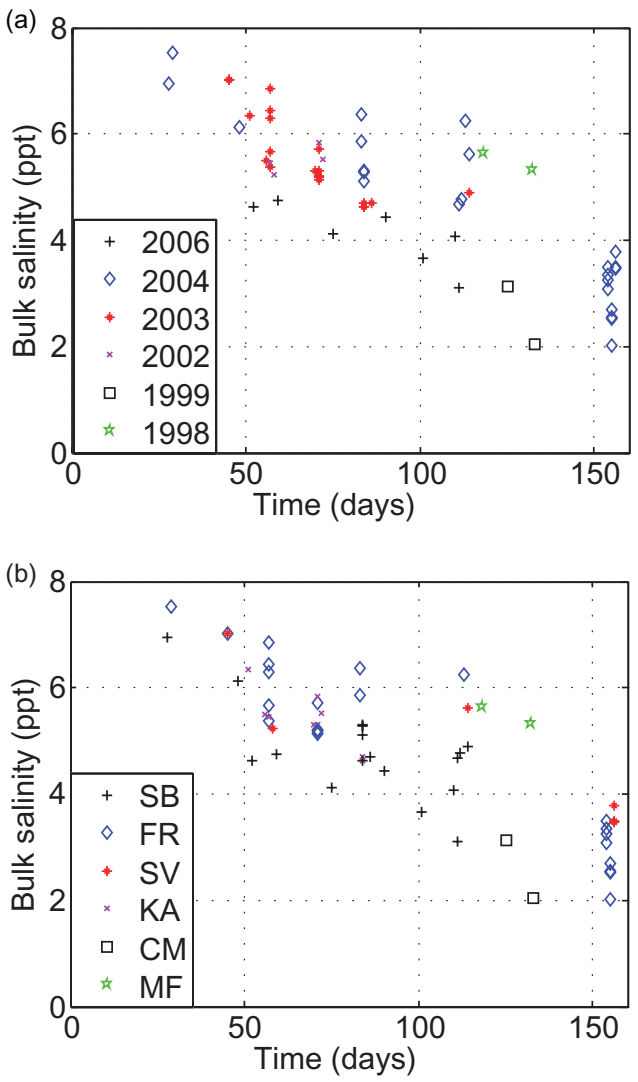

Fig. 6 Bulk (averaged over the ice thickness) salinity measurements, grouped by (a) year and (b) station.

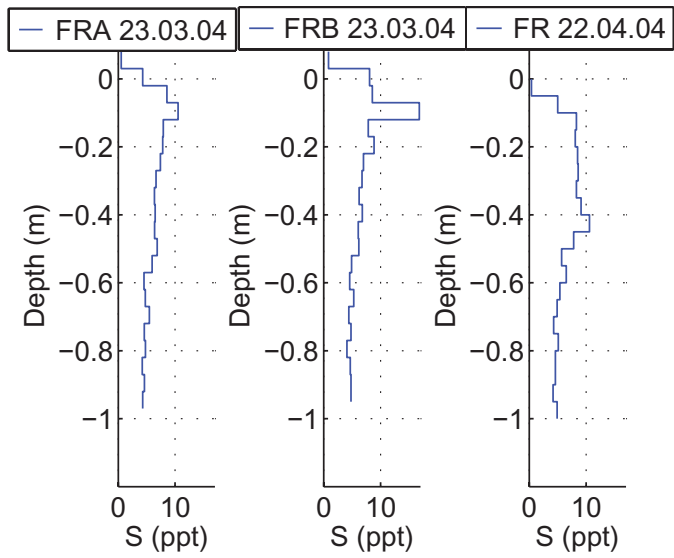

Fig. 7 Some salinity profiles at FR 2004. The central and left plots (FRA230304 and FRB230304) show measurements from 23 March, and the plot to the right (FR220404) is from 22 April.

conductive flux up through the ice, nor to whether $-1.92^{\circ} \mathrm{C}$ or $-2^{\circ} \mathrm{C}$ was used as the freezing point. Some calculations of the oceanic flux for parts of the 2002 and 2003 seasons were also undertaken, from the first day
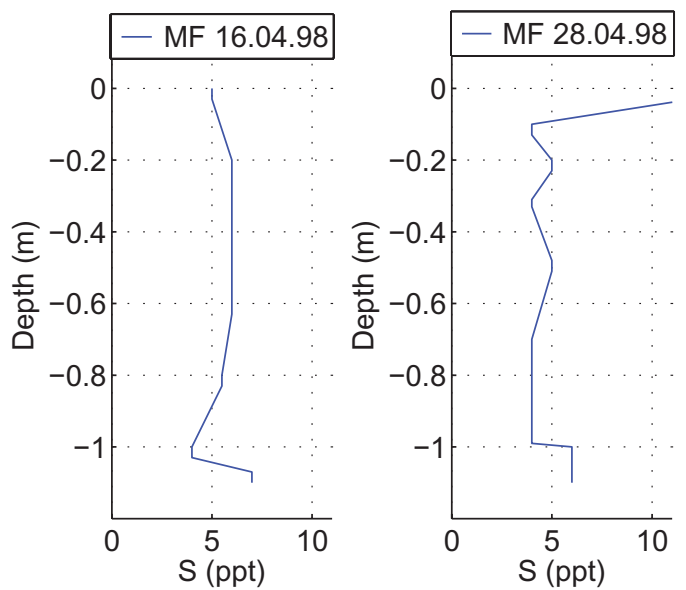

Fig. 8 Salinity profiles at MF in 1998

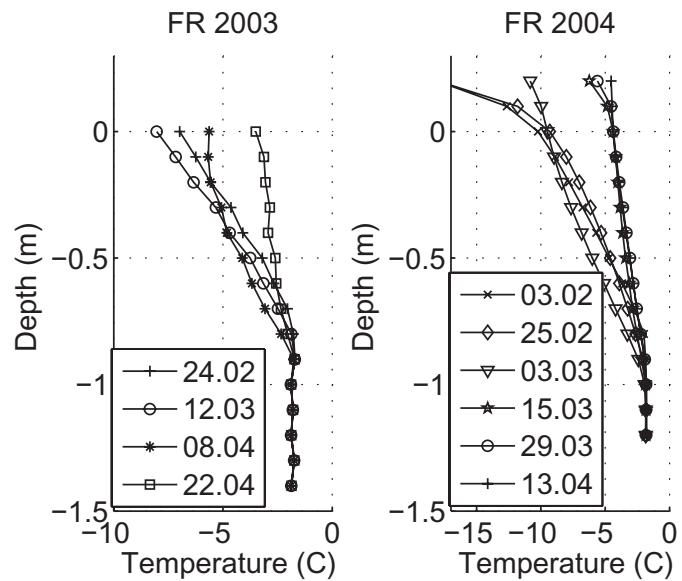

Fig. 9 Temperature versus depth plots for FR in 2003 and 2004

of measurements (mid-February) until the freeboard became negative (early/mid-March). These results generally show that the oceanic flux for the Svartodden case was lower when the ice was not submerged. However, for these short time periods, the results are sensitive to 1 or $2 \mathrm{~cm}$ difference in input ice thickness, and we did not measure ice thickness exactly the day(s) before the snow accumulation started.

\section{Discussion}

\section{Formation and ridging}

Anecdotal and other data on ice formation and break-up are sumarized in Table 5. Sundström (2002) 
Fig. 10 Measured and calculated ice growth.

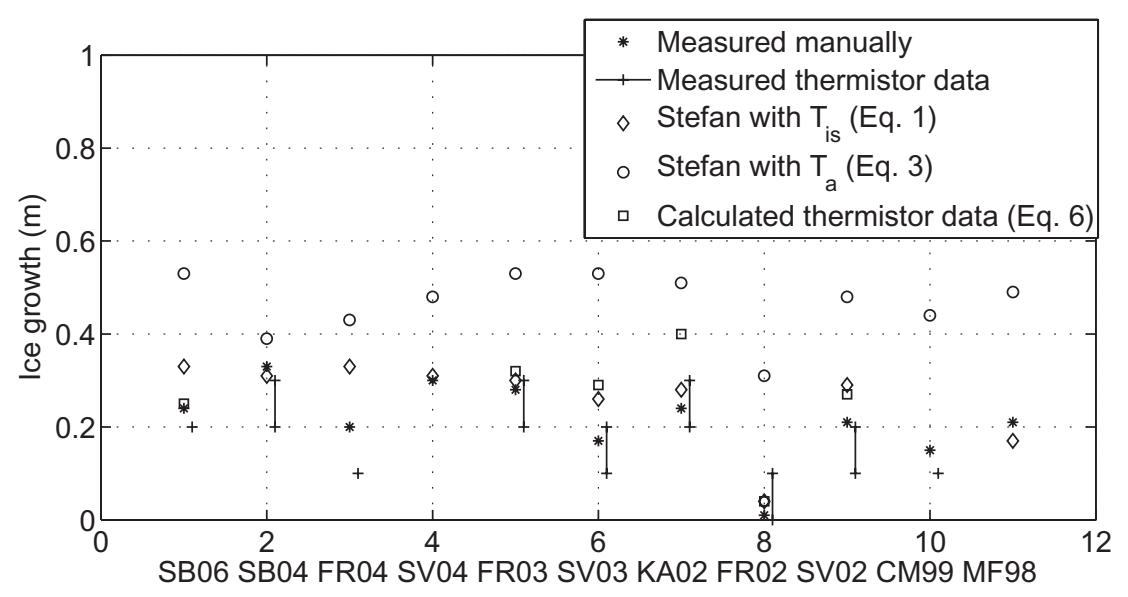

Table 3 Material parameters used in simulations.

\begin{tabular}{llll}
\hline$k$ & $\rho$ & $I_{\mathrm{pi}}$ & $I_{\mathrm{si}}$ \\
\hline $\mathrm{W} \mathrm{C}^{-1} \mathrm{~m}^{-1}$ & $\mathrm{~kg} \mathrm{~m}^{-3}$ & $\mathrm{~kJ} \mathrm{~kg}^{-1}$ & $\mathrm{~kJ} \mathrm{~kg}^{-1}$ \\
2.2 & 920 & 333.4 & 282.3 \\
\hline
\end{tabular}

interviewed people who had been working in Svea since the early 1980s, and they all claim that the ice in the inner basin breaks up in the first half of July. One of Sundström's interviewees, a hunter who has been living on Akseløya for periods since the beginning of the 1980s, stated that in the outer basin the ice broke up around 26 July in 1980 and 1981. According to this interviewee, the ice generally broke up 2 weeks earlier in the 1990s than in the 1980s. In 2006, which was a warm winter with no fast ice in the outer basin, the ice in the inner basin left the first week of June (Fabrice Caline, UNIS, pers. comm.), which is about 1 month earlier than during previous years.

An automatic camera that took diurnal pictures from the shoreline close to the site SV was installed by Frank Nilsen (UNIS) in 2003. It showed that the ice broke up and drifted out of the outer basin on the 23 June. The outer basin was more or less ice-free after this, but occasional pieces of ice floated by in the following weeks. A second wave of ice floated by the camera on 8 July, and was likely to have been ice from the inner basin. There was no ice after 26 July (Frank Nilsen, UNIS, pers. comm.).

The time for freeze-up covers a wider time span. According to Sundström (2002), the ice settles in November or December, sometimes as late as January in the inner basin. The hunter on Akseløya that Sundström interviewed stated that the ice normally settled in November in the 1980s, but rarely until December in the 1990s.

The yearly variation in ridging intensity is related to the weather situation at certain ice thicknesses. The block thickness in all ridges was about $0.10-0.15 \mathrm{~m}$, meaning that if the weather is quiet until the ice grows thicker than this, there will be few ridges. In 2004, when December and January were very cold and calm, the ice cover was very even. The ice cover was too thick for wind and currents to deform it.

\section{Ice thickness}

In general, ice thickness depends on several factors: meteorological conditions (air temperature, radiation, snow and wind), oceanic conditions (velocity, salinity and temperature) and physical constraints on ice movements, such as islands. In a closed bay, a thin ice cover will be less exposed to waves and winds, and even if the ice is broken, it will more often stay and refreeze. Our measurements of ice thickness show consistent variation between the different stations and the different years. Air temperatures, snow depths and the oceanic flux explain these temporal and spatial variations, and the confining effect of Akseløya explains the relatively thick ice cover in Van Mijenfjorden compared with other western Spitsbergen fjords.

Let us first consider the air temperature and snow accumulation. The spatial differences in the outer basin can be explained by the snow thickness and oceanic conditions. The local wind system accumulated less snow on the southern side (see Fig. 4), and this gave less insulation and higher ice growth for the first and middle part of the season (see below for further discussion on the difference between FR and SV in relation to the oceanic conditions).

The peak seasonal ice thicknesses in our measurement period were between 0.72 and $1.28 \mathrm{~m}$, and these were from cold and warm winters, respectively. All of the stations had high ice thicknesses in cold winters and corresponding low thicknesses in warm winters. Carstens et al. (1979) measured ice and snow thickness at three 
Table 4 Summary of the calculations: the freezing degree days (FDDs), the measured ice growth (manually and by temperature records) and the ice growth calculated with Eqns. 1, 3 and 6, and the conductive and oceanic flux.

\begin{tabular}{|c|c|c|c|c|c|c|c|c|c|c|}
\hline \multirow[b]{2}{*}{ Station } & \multirow[b]{2}{*}{ Period } & \multirow{2}{*}{$\begin{array}{l}F D D \\
\text { (days) }\end{array}$} & \multirow{2}{*}{$\begin{array}{l}\Delta h_{i}^{\mathrm{M}} \\
(\mathrm{m})\end{array}$} & \multirow{2}{*}{$\begin{array}{c}\Delta h_{i}^{T} \\
(\mathrm{~m})\end{array}$} & \multicolumn{3}{|l|}{$\Delta h_{i}(m)$} & \multirow{2}{*}{$\begin{array}{l}\omega \\
(-)\end{array}$} & \multirow{2}{*}{$\begin{array}{l}q_{\text {cond,avg }} \\
\left(\mathrm{W} \mathrm{m}^{-2}\right)\end{array}$} & \multirow{2}{*}{$\begin{array}{l}\text { qocean } \\
\left(\mathrm{W} \mathrm{m}^{-2}\right)\end{array}$} \\
\hline & & & & & Eqn. 1 & Eqn. 3 & Eqn. 6 & & & \\
\hline \multicolumn{11}{|c|}{2006} \\
\hline SB & $21.02-19.04$ & 672 & 0.24 & 0.2 & $\begin{array}{l}0.33 \\
2004\end{array}$ & 0.53 & 0.25 & 0.37 & -13 & $0.12-0.45$ \\
\hline SB & $28.01-20.04$ & 900 & 0.33 & $0.2-0.3$ & 0.31 & 0.39 & $0.31-0.32$ & 0.83 & -10 & $0.18-(-0.69)$ \\
\hline $\mathrm{FR}$ & $29.01-22.04^{a}$ & 783 & 0.20 & 0.1 & 0.33 & 0.43 & $0.33-0.35$ & 0.4 & -12 & $4.7-5.6$ \\
\hline SV & $29.01-22.04$ & 905 & 0.30 & - & $\begin{array}{l}0.31 \\
2003\end{array}$ & 0.48 & & 0.7 & - & - \\
\hline $\mathrm{FR}$ & $14.02-23.04$ & 877 & 0.28 & $0.2-0.3$ & 0.30 & 0.53 & 0.32 & 0.47 & -14 & $1.9-2.5$ \\
\hline SV & $14.02-23.04$ & 877 & 0.17 & $0.1-0.2$ & $\begin{array}{l}0.26 \\
2002\end{array}$ & 0.53 & 0.29 & 0.26 & -10 & $2.5-2.8$ \\
\hline $\mathrm{KA}$ & $20.02-14.05$ & 937 & 0.31 & & & 0.57 & & 0.45 & & \\
\hline $\mathrm{KA}$ & $27.02-14.05$ & 866 & 0.24 & $0.2-0.3$ & 0.28 & 0.51 & 0.24 & 0.4 & -10 & $0.4-0.89$ \\
\hline FR & $03.04-25.04$ & 655 & 0.01 & $0-0.1$ & 0.04 & 0.31 & 0.04 & 0.25 & -5 & $3.6-5.1$ \\
\hline SV & $27.02-25.04$ & 737 & 0.21 & $0.1-0.2$ & $\begin{array}{l}0.29 \\
1999\end{array}$ & 0.48 & 0.27 & 0.4 & -14 & $3.5-3.8$ \\
\hline $\mathrm{CM}$ & $10.03-05.05$ & 680 & 0.15 & 0.1 & $\begin{array}{l}0.17 \\
1998\end{array}$ & 0.44 & & 0.29 & & \\
\hline MF & 03.03-12.05 & 985 & 0.21 & & & 0.49 & & 0.39 & & \\
\hline MF & $16.04-12.05$ & 145 & 0.06 & & 0.07 & 0.09 & & 0.6 & & \\
\hline
\end{tabular}

ace melted between 23 March and 22 April.

Table 5 Summary of ice formation and break-up.

\begin{tabular}{llll}
\hline Year & Formation & Break-up & References \\
\hline & & Inner basin & \\
1980 s & November-January & First half of July & Sundström 2002 \\
1990 s & November-January & First half of July & Sundström 2002 \\
1998 & Early December & V. Tverberg, pers. comm. \\
2003 & & 7-8 July & pers. observ. \\
2006 & First week of January & First week of June & F. Caline, pers. comm. \\
& & Outer basin & \\
1980,1981 & Late July & Sundström 2002 \\
1980 s & November & & Sundström 2002 \\
1990 s & December & Sundström 2002 \\
2003 & 23 June & F. Nilsen, pers. comm. \\
2006 & No fast ice & & pers. observation \\
\hline
\end{tabular}

spots in the vicinity of the KA site in 1978, and he found a seasonal peak ice thickness in mid-May between 1.4 and $1.6 \mathrm{~m}$ and snow accumulation of $0.1-0.2 \mathrm{~m}$. However, the winter of $1977 / 78$ was quite cold, with an average winter temperature of $-12.7^{\circ} \mathrm{C}$. If we take the average winter air temperature since $2000\left(-8.97^{\circ} \mathrm{C}\right)$, the average peak ice thickness $(1.01 \mathrm{~m})$, apply Stefan's Law, and compare with the data from Carstens et al. (1979), then the ratios between the $h_{i}$ values and the ratio of the square root of the FDDs become different, an ice thickness of $1.3 \mathrm{~m}$ in 1978 would be needed to get equal ratios. This means that Carsten's ice thickness could have been rafted ice, but it is also reasonable to think that the un-deformed ice was thicker than in the early 2000s. There is a clear trend of increasing average air temperatures, both during the winter or annually, from the 1980s through the 1990s and into the 2000s (Figs. 11, 12). This is in line with anecdotal observations by Sundström's interviewee (Sundström 2002).

The effect of oceanic conditions was clear in 2006, when no fast ice was formed in the outer basin, in spite of drifting ice and air temperatures well below the freezing point. This can be attributed to the progressive warming of the West Spitsbergen Current that has been observed since 2004 (Cottier et al. 2007; Walczowski \& Piechura 2007). Furthermore, the correlation between air temperatures and ice thicknesses (Figs. 11, 12) appears to be weaker, which can also be attributed to the warmer 
Fig. 11 Annual average air temperatures, measured at Longyearbyen (LYB) and Svea.

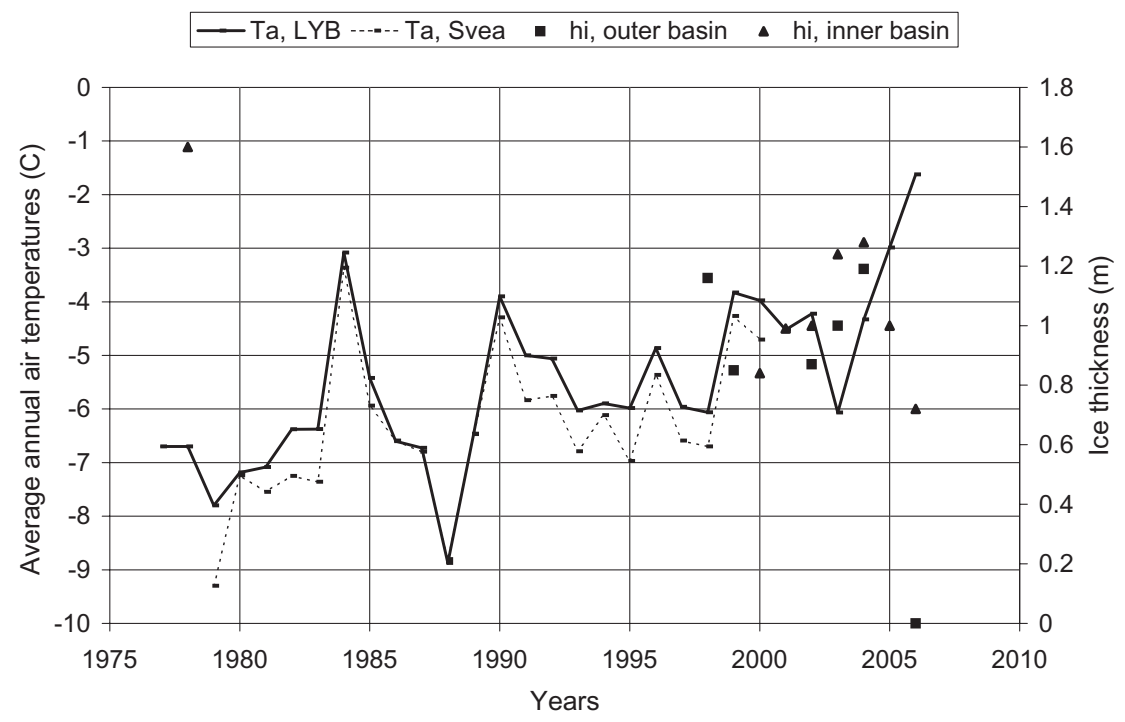

Fig. 12 Average winter air temperatures (November-May), measured at Longyearbyen (LYB) and Svea.

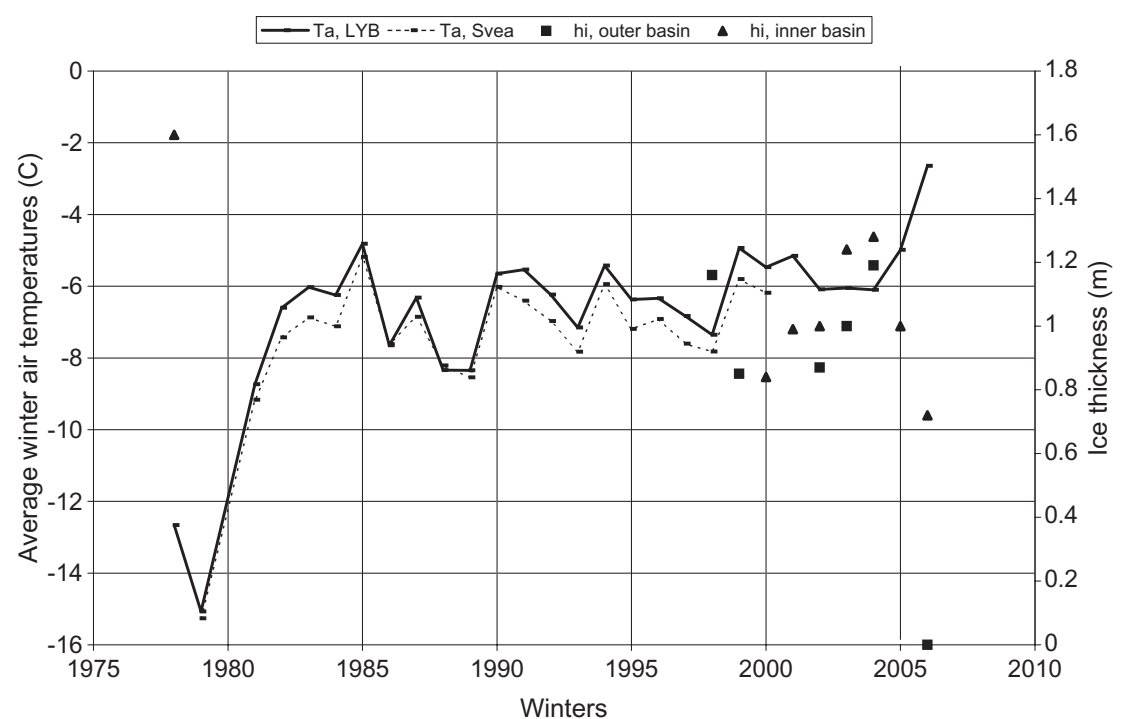

water. The earlier melting of the ice at FR compared with SV in the late spring of 2004 also demonstrates the effect of the oceanic flux. The tidal current is stronger on the southern side of the fjord, so the effects of warm water will be more pronounced there (Bergh 2004).

The physical constraint on ice movement and wave action, such as that provided by Akseløya, affects ice thickness, mostly through the timing of the freeze-up. Gerland \& Hall (2006) report an average peak thickness of $0.71 \mathrm{~m}$ over several years (1997-98, 2000 and 200205) in Kongsfjorden, situated further north in western Spitsbergen. The settlement of Ny-Ålesund, by the fjord, generally has more FDDs than Van Mijenfjorden, but Kongsfjorden is not partially blocked as Van Mijenforden is by the island of Akseløya.

\section{Ice thickness calculations}

Stefan's Law, based on air temperatures (Eqn. 3), overestimates ice growth because it does not include the snow cover, the solar radiation, the oceanic flux or the thermal inertia. The neglect of the first three of these factors results in an overestimation of ice growth, but the lack of thermal inertia may contribute to lowering the modelled growth. In a case in which the ice is quite cold at $t=t_{0}$ and warm at $t$ (as in 2004), the negative energy initially stored in the ice will contribute to ice growth in a way that is not predicted by Stefan's Law. The empirical coefficient $(\omega)$ may account for the missing factors, but only if the relationship among the contributions from the missing factors balance each other. The $\omega$ value for the 2004 
season was substantially higher than for the other years. This is because the winter of 2004 was a bit different than the others, with a rather cold December and January, an ordinary February, and an unusually warm March and April. Almost all of the growth took place early in the season, and it stopped fairly early on. The snow cover during the growth season was thin, and the precipitation in the second half of the winter insulated the ice from the warm atmosphere, so that the thermal inertia of the cold ice could contribute to further ice growth. For the other years, an $\omega$ value of $0.3-0.4$ seems reasonable. This is also in line with Leppäranta \& Hakala's (1989) value for the Baltic $(\omega=0.35-0.4)$. The overall advantage of Eqn. 3 is its simplicity, both in use and in the need for input data: an air-temperature record is often available. Another well know equation is Zubov's empirical expression $\left(h_{\mathrm{i}}^{2}+50 h_{\mathrm{i}}=8 F D D\right)$, but this expression results in too high thickness for the thinner peak ice thickness, and not enough ice for the higher peak thicknesses.

When using the measured snow-ice interface temperature (Eqn. 1) or the measured ice temperatures (Eqn. 6), the models fit well, with the latter model fitting slightly better than the former. But, they both overpredict the thickness at SV in 2003 (and partly in 2002), when the ice was flooded. This may be caused by measurement errors or because of the flooding itself, as discussed below. The three equations (1,3 and 6) are all based on the same physics (Eqn. 4, with $q_{\text {ocean }}=0$ ), but in Eqns. 1 and 6 there is no need to assume anything about the snow depth, and this improves these estimates considerably. The difference between Eqns. 1 and 6 is more subtle. The difference lies in how much of the ice cover is used to estimate $q_{\mathrm{i}}$. In principle it is only the gradient in a thin boundary layer at the bottom of the ice cover that drives the freezing. But, to get a good estimate of a temperature gradient, one needs several measurement points. Equation 6 should, in principle, be better because it is less affected by surface conditions and more affected by any heat from the ocean.

The calculated oceanic fluxes were on the order of a few $\mathrm{W} \mathrm{m}^{-2}$. This compares well with Leppäranta (1993), who referred to Badgley (1966) and Maykut (1986), who suggested typical values for the Arctic on the order of l-5 $\mathrm{W} \mathrm{m}^{-2}$. The calculated fluxes show a clear difference between the inner basin (KA and SB) and the outer basin (FR and SV). This suggests that the tidal current, which we assume is the main source of the oceanic flux, has a substantially higher effect in the outer basin. The difference between KA and SB is also reasonable, as SB lies further in and is in the middle of Sveabukta. The melting of ice at FR in May 2004 compared with SV is also an effect of the oceanic flux, but the difference between FR and SV in the outer basin in 2003 is more difficult to explain. The tidal current is stronger at FR, and when warm water enters the fjord it should have a greater impact at FR, that is, the oceanic flux should be larger or equal to that at SV. In 2003 the ice was submerged at SV by a thick snow layer, which may account for the higher estimate of the oceanic flux. As only part of the ice cover in the fjord is submerged, it could affect the hydrodynamics so that the level of turbulence changes, provoking changes in the oceanic flux. The hydrodynamics of the fjord is outside the scope of this paper, and I will only describe one other phenomenon that could explain the estimated differences in $q_{\text {ocean }}$. When the ice was flooded, brine started to migrate downwards in the ice cover, and as the temperature profile was positive (ice warmer further down), some ice melted as the brine drizzled down. The melting consumed heat, cooled down the ice and acted as a heat source, which is not accounted for in the numerical scheme. This internal melting can be added, yielding the following the thermal balance equation:

$$
q_{\text {ocean }}+q_{\mathrm{i}}+q_{\text {lat }}^{\text {bottom }}+q_{\text {lat }}^{\text {internal }}=0
$$

where the three first terms are treated as external forces, as in Eqn. 4, and the last term accounts for the internal melting/freezing. If we suggest that the effect of internal melting overestimates the calculations of $q_{\text {ocean }}$ by $2 \mathrm{~W} \mathrm{~m}^{-2}$, then ice corresponding to $1.5 \%$ of the ice thickness must have melted every month. This may very well be a reasonable number, and suggests that the brine drainage may directly affect the heat transfer in first-year sea ice.

\section{Salinity}

Figure 13 shows a plot of bulk (or average) salinity against ice thickness. The figure also includes the best fit

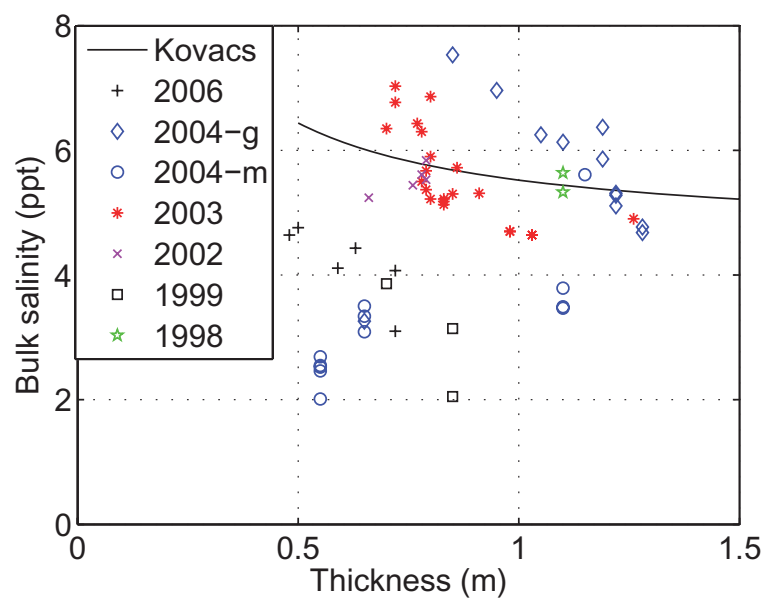

Fig. 13 Bulk salinity versus ice thickness: 2004-g is growing ice, whereas 2004-m is melting ice. 
equation of Kovacs (1997) for winter ice. Our winter ice data (except 2006) are nicely spread around Kovacs' best fit equation (4-6 ppt). The winter of 2006 was warm, and even though the ice grew, melting also occurred during the season, and brine drained. The higher air temperatures have two major effects: firstly, it gives a lower growth rate, so that less brine is captured as the ice grows, and secondly, it allows for faster brine drainage. The higher salinity with higher growth rate can easily be seen in Figs. 6 and 13, where the 2004 salinities were the highest (except for those in June when the ice was melting). The salinities reported by Nakawo \& Sinha (1981) are a bit higher than ours, but the air temperatures were lower during their measurements. Our melting ice salinities (the 2004-m data presented in Fig. 13 and the 1999 measurements) also correspond to those reported by Kovacs (1997).

The salinity profiles of growing first-year sea ice usually have a c-shape, with high salinity at the top and bottom. Most of our profiles had such a c-shaped profile. But when the ice stops growing, the skeleton layer disappears, and so does the high bottom salinity (as can be seen in Fig. 7). As discussed above, a deviation from c-profiles also occurs during melting of the snow or the ice, or if it rains, so that freshwater ice forms.

\section{Conclusions}

Measurements of ice and snow thickness, freeboard and salinity have been carried out in several stations during the winter season in Van Mijenfjorden in Svalbard, Norway, in the years 1998-2004 and 2006. Ice thickness was measured manually and with thermistor strings. Simple models were used to estimate the measured ice thicknesses, and to estimate the oceanic flux. A consistent connection between the annual and spatial ice thickness differences, the air temperatures, the local snow accumulation and the oceanic conditions is shown. The main findings are:

- The peak seasonal ice thickness was measured in 2004, with $1.28 \mathrm{~m}$ in the inner basin and $1.19 \mathrm{~m}$ in the outer basin; the winter of 2004 was a cold winter.

- The minimum peak ice thickness was $0.72 \mathrm{~m}$ in the inner basin and no fast ice in the outer basin in 2006; the winter of 2006 was a warm winter, and the water was also unusually warm.

- The inner basin has thicker ice than the outer basin, most probably because of earlier freeze-up and lower oceanic flux.

- The oceanic flux in the outer basin was $2-5 \mathrm{~W} \mathrm{~m}^{-2}$, and about zero in the inner basin.

- In the outer basin, the southern side has thicker ice during winter and early spring because of less snow, but thinner ice late in the spring because of higher oceanic flux.

- Flooding may cause an overestimation of the oceanic flux in a purely thermal analysis.

- Different ice growth mechanisms occurred, and the simplest version of Stefan's Law must be applied with care.

- There is reason to believe that the ice conditions were lighter compared with the 1980s.

\section{Acknowledgements}

I would like to thank the students who participated in the UNIS course AT-208 (Thermo-mechanical properties of materials) during the years 2002-2006. I am also grateful to my former colleague Associate Professor Frank Nilsen, and the students in his course AGF-211. The students Arne Langeland, Morten Kyhring, Tor Villy Kangas, Rudiger Biedorf, Sergeij Vernyayev and Sigurd Ellingsen Lie all worked on Van Mijenfjorden as part of their Master's degrees, and they did a lot of great work. The PhD students Per Olav Moslet (during 2002-04) and Sebastién Barrault (in 2006) were always very helpful assisting in the field and helping other students. Sveinung Løset introduced me to fieldwork in Van Mijenfjorden in 1997, and has also been in the fjord on several occasions: his help is much appreciated. Store Norske Spitsbergen Kullkompani has supported this work with logistics, funding and general assistance. The help of Anja Angelsen has improved the English language and thereby the readability of this paper, this help is much appreciated. Finally, I would like to thank the two anonymous reviewers that have contributed to making the paper clearer and easier to read.

\section{References}

Badgley F.I. 1966. Heat balance at the surface of the Arctic Ocean. In J.E. Fletcher (ed.): Proceedings of the Symposium on the Arctic Heat Budget and Atmospheric Circulation. Pp. 215-246. Santa Monica, CA: Rand Corporation.

Barrault S. \& Høyland K.V. 2007. Mechanisms and measurements of generation of stresses in first-year landfast sea ice. In Q. Yue \& S. Ji (eds.): POAC '07: recent development of offshore engineering in cold regions. Proceedings of the 19th International Conference on Port and Ocean Engineering under Arctic Conditions. Vol. 2. Pp. 685-694. Dalian, China: Dalian University of Technology Press.

Bergh J. 2004. Measured and modelled tidally driven mean circulation under ice cover in Van Mijenfjorden. Master's thesis, Göteburg University/University Courses in Svalbard.

Caline F. \& Barrault S. 2008. Transmission of level ice stresses to ice foot through a tidal crack. In M. Jasek (ed.): Proceedings of 19th IAHR International Symposium on Ice. 
Vol. 2. Pp. 831-840. Vancouver, BC: International Association of Hydraulic Engineering and Research. Carstens T., Karal K. \& Kjeldgaard J.H. 1979. Svea kaiprosjekt-isundersøkelser. (Svea wharf project-ice investigations.) Technical Report SINTEF STF60 A79006. Trondheim: Vassdrags og Havnelaboratoriet, Norwegian Institute of Technology.

Cottier F.R., Nilsen F., Hall M., Gerland S., Tverberg V. \& Svendsen H. 2007. Wintertime warming of an Arctic shelf in response to large-scale atmospheric circulation. Geophysical Research Letters 34, L10607, doi: 10.1029/ 2007 GL029948.

Eicken H., Fisher H. \& Lemke P. 1995. Effects of the snow cover on Antarctic sea ice and potential modulation of its response to climate change. Annals of Glaciology 21, 369-376.

Gabrielsen M., Barrault S., Caline F. \& Høyland K.V. 2008. Comparison of physical and mechanical properties of coastal ice and level ice. In M. Jasek (ed.): Proceedings of 19th IAHR International Symposium on Ice. Vol. 2. Pp. 956-974. Vancouver, BC: International Association of Hydraulic Engineering and Research.

Gerland S. \& Hall R. 2006. Variability of fast-ice thickness in Spitsbergen fjords. Annals of Glaciology 44, 231-239.

Høyland K.V. 2002. Consolidation of first-year sea ice ridges. Journal of Geophysical Research-Oceans 107, article no. 3062, doi: 10.1029/2000JC000526.

Kangas T.V. 2000. Thermohaline sesongvariasjoner $i$ Van Mijen fjorden. (Seasonal thermohaline variations in Van Mijenfjorden.) Master's thesis, University Courses in Svalbard/Dept. of Geophysics, University of Bergen.

Kovacs A. 1997. The bulk salinity of Arctic and Antarctic sea ice versus ice thickness. In H. Yamaguchi et al. (eds.): Proceedings of the 16th International Conference on Offshore Mechanics and Arctic Engineering. Vol. 4. Arctic/polar technology. Pp. 271-281. New York: American Society of Mechanical Engineers.

Leppäranta M. 1993. A review of analytical models of sea-ice growth. Atmosphere-Ocean 31, 123-138.

Leppäranta M. \& Hakala R. 1989. Field measurements of the structure and strength of first year ice ridges in the Baltic Sea. In J.S. Chung et al. (ed.): Proceedings of the Eighth International Conference on Offshore Mechanics and Arctic Engineering. Vol. 4. Arctic and polar technology. Pp. 169-174. New York: American Society of Mechanical Engineers.

Maykut G.A. 1986. The surface heat and mass balance. In N. Untersteiner (ed.): The geophysics of sea ice. Pp. 395-463. New York: Plenum Press.

Maykut G. \& Understerner N. 1971. Some results from a time-dependent thermodynamical model of sea ice. Journal of Geophysical Research 76, 1550-1575.
Michel B. \& Ramseier R. 1971. Classification of river and lake ice. Canadian Geotechnical Journal 8(36), 36-45.

Moslet P.O. 2001. Estimation of loads exerted by sea ice on the quay at Kapp Amsterdam, the Van Mijen Fjord. Master's thesis, University Courses in Svalbard/Dept. of Structural Engineering, Norwegian University of Science and Technology.

Moslet P.O. 2007. In-situ measurements of sea-ice parameters that affect the ice loads on coastal and offshore structures. PhD thesis, Norwegian University of Science and Technology.

Moslet P.O. \& Høyland K.V. 2003. In-situ measurements of ice stresses on Svalbard. In S. Loset et al. (eds.): Proceedings: 17th International Conference on Port and Ocean Engineering under Arctic Conditions. Pp. 283-292. Trondheim: Norwegian University of Science and Technology.

Nakawo M. \& Sinha N. 1981. Growth rate and salinity profile in first-year sea ice in the High Arctic. Journal of Glaciology 27, 315-329.

Nicolaus M., Haas C. \& Bareiss J. 2003. Observations of superimposed ice formation at melt-onset on fast ice on Kongsfjorden, Svalbard. Physics and Chemistry of the Earth 28, 1241-1248.

Shafrova S. \& Moslet P.O. 2006a. In-situ uniaxial compression tests of level ice. Part I: ice strength variability versus length scale. In: Proceedings of the 25th International Conference on Offshore Mechanics and Arctic Engineering. OMAE-92450. New York: American Society of Mechanical Engineers.

Shafrova S. \& Moslet P.O. 2006b. In-situ uniaxial compression tests of level ice. Part II: ice strength spatial distribution. In: Proceedings of the 25th International Conference on Offshore Mechanics and Arctic Engineering. OMAE-92451. New York: American Society of Mechanical Engineers.

Stefan J. 1891. Über die Theorie der Eisbildung, insbesondere über die Eisbildung im Polarmeere. (The theory of ice formation, especially regarding ice formation in the Polar Sea.) Annalen der Physik und Chemie 42, 269-286.

Sundström H. 2002. Sea ice history in the Van Mijen fjord. Technical report. Longyearbyen, Norway: University Courses on Svalbard.

Teigen S.H., Høyland K.V. \& Moslet P.O. 2005. Thermal stresses in first-year sea ice. In J.P. Dempsey (ed.): Proceedings: 18th International Conference on Port and Ocean Engineering under Arctic Conditions. Vol. 2. Pp. 893-903. Potsdam, NY: Clarkson University.

Walczowski W. \& Piechura J. 2007. Pathways of the Greeland Sea warming. Geophysical Research Letters 34, L10608, doi: 10.1029/2007GL029974. 